\title{
PENGARUH SUPERVISI, KEMAMPUAN KOGNITIF, DAN KOMITMEN ORGANISASI TERHADAP KEMAMPUAN ADAPTASI KARYAWAN
}

\author{
Supriyadi ${ }^{(1)}$, Nurpalah ${ }^{(2)}$ \\ supriyadi@stembi.ac.id ${ }^{(1)}$, dn3stembi@gmail.com ${ }^{(2)}$ \\ (1) Dosen Program Studi Manajemen STIE STEMBI - Bandung Business School, \\ Peneliti Junior STIE STEMBI - Bandung Business School ${ }^{(2)}$
}

\begin{abstract}
Ringkasan
Hal penting yang perlu diperhatikan dalam proses merger adalah bagaimana karyawan dapat beradaptasi dengan suasana organisasi baru hasil merger. Penelitian ini bertujuan untuk menganalisis pengaruh Supervisi, Kemampuan Kognitif, dan Komitmen Organisasi terhadap Kemampuan Adaptasi Karyawan. Desain penelitian ini adalah deskriptif verifikatif dengan alat analisis statistic menggunakan multiple regreesion. Unit analisisnya adalah karyawan perusahaan yang dipertahankan dari sebuah proses hasil merger. Data dikumpulkan dengan kuesioner. Temuan dari penelitian ini menunjukan bahwa secara simultan, supervise, kemampuan kognitif dan komitmen organisasi merupakan factor penentu yang signifikan atas perubahan kemampuan adaptasi karyawan. Selain itu, penelitian ini memperlihatkan bahwa secara parsial, Kemampuan Kognitif dan Komitmen Organisasi berpengaruh signifikan terhadap Kemampuan Adaptasi Karyawan. Sementara itu, supervisi tidak menunjukan adanya pengaruh yang signifikan.
\end{abstract}

Kata kunci: Supervisi; Kemampuan Kognitif; Komitmen; Adaptasi.

\section{A. PENDAHULUAN}

Pemberdayaan karyawan menjadi suatu hal yang penting, karena didalam menghadapi era persaingan dan pelayanan, setiap organisasi membutuhkan karyawan yang cepat tanggap dan mandiri sehingga organisasi mempunyai keunggulan kompetitif melalui sumber daya manusia, termasuk untuk memunculkan potensi dan modalitas yang ada dalam diri karyawan dan memaksimalkannya. Semakin cepatnya perubahan dalam berbagai aspek baik eksternal maupun internal, menuntut perusahaan untuk selalu dapat menyesuaikan diri dengan lingkungannya. Tak pelak lagi, kebutuhan atas karyawan yang mampu beradaptasi secara cepat dengan lingkungannya menjadi sesuatu yang sangat urgent.

Aktivitas merger sebuah perusahaan seringkali membawa dampak pada karyawan. Salah satunya adalah, bagi karyawan yang dipertahankan, mereka berhadapan dengan suasana baru, cara-cara kerja dan budaya organisasi yang baru, target dan ketentuanketentuan baru, serta gaya kepemimpinan yang baru. Semua itu membutuhkan kemampuan adaptasi yang cepat. Namun, tidak semua karyawan menyadari hal tersebut. Kebanyakan, mereka masih terbiasa dengan ritme dan pola kerja yang lama.
Banyak cara yang dapat dilakukan oleh perusahaan untuk mempercepat adaptasi karyawan dalam sebuah perubahan. Cara yang paling umum adalah dengan melakukan aktivitas supervisi yang intensif kepada karyawan. Berbagai perubahan dan cara-cara baru disosialisasikan secara massif. Seorang supervisor memainkan peran yang sangat vital untuk mengkomunikasikan kebijakan perusahaan sebagai konsekwensi merger.

Selain itu, kemampuan adaptasi karyawan sering juga berhubungan erat dengan situasi internal invidu karyawan yang bersangkutan. Bagaimanapun juga, adaptasi adalah sebuah proses yang melibatkan aspekaspek psikologis karyawan. Kemampuan kognitif dan Komitmen organisasi diduga mempunyai kontribusi bagi kecepatan adaptasi seorang karyawan.

Berdasarkan uraian diatas, penulis tertarik untuk mengadakan penelitian mengani kemampuan adaptasi karyawan pada lingkungan kerja dan suasana kerja yang baru sebagai dampak dari aktivitas merger perusahaannya. Penelitian ini bertujuan untuk mendapatkan hasil analisis dan bukti empiris mengenai pengaruh Supervisi, Kemampuan kognitif, dan Komitmen Organisasi terhadap Kemampuan Adaptasi. 


\section{B. LANDASAN TEORI}

Kemampuan adaptasi adalah kemampuan menyesuaikan diri dengan lingkungan. Penyesuaian diri merupakan suatu proses alamiah dan dinamis yang bertujuan untuk mengubah perilaku individu agar terjadi hubungan yang lebih baik sesuai dengan kondisi lingkungannya (Aziz:2015). Selanjutnya Desmita (2014) menuliskan pengertian proses penyesuaian diri yang berisi: "Pengertian luas tentang proses penyesuaian terbentuk sesuai dengan hubungan individu dengan lingkungan sosialnya, yang dituntut dari individu tidak hanya merubah kelakuannya dalam menghadapi kebutuhan-kebutuhan dirinya dalam dan keadaan diluar, dalam lingkungan dimana dia hidup, akan tetapi juga dituntut untuk menyesuaikan diri dengan adanya orang lain dan macam-macam kegiatan mereka, jika mereka ingin penyesuaian, maka hal itu menuntut adanya penyesuaian antara keinginan masing-masingnya dengan suasana lingkungan sosial tempat mereka bekerja".

Menurut Semiun (2007: 41-48) untuk mengungkapkan tinggi rendahnya kemampuan adaptasi digunakan kriteria kemampuan adaptasi sebagai indikator yaitu: 1). Self knowledge, adalah kemampuan mengetahui potensi-potensi dan kekurangan yang dimiliki; 2). Self objectivity,adalah kemampuan untuk berfikir secara objektif untuk melihat sebuah penyebab kegagalan dalam melakukan pekerjaan dan memperbaiki kegagalan agar berikutnya tidak melakukan kesalahan yang sama; 3). Self control, adalah kemampuan untuk mengendailkan emosi, pikiran, kebiasaan, sikap dan tingkah laku saat mengatasi masalah yang dihadapi, serta kemampuan mengembangkan diri menjadi lebih baik; 4). Good interpersonal relationship, adalah kemampuan untuk menunjukkan hubungan interpersonal yang baik dengan orang lain; 5). Satisfication in work, adalah rasa puas yang diperoleh dari segala aktivitas kerja yang dilakukan karyawan.

\section{Supervisi dan Kemampuan Adaptasi}

Supervisi sering juga diterjemahkan sebagai pengawasan. Supervisi ialah suatu aktivitas pembinaan yang direncanakan untuk membantu karyawan dalam melakukan pekerjaan mereka secara efektif (Purwanto, 2009:76). Pengawasan merupakan salah satu fungsi manajemen yang merupakan kegiatankegiatan yang berada pada tanggung jawab pemimpin untuk mencapai tujuan organisasi melalui pengawasan dan evaluasi kinerja perusahaan (Fahmi, 2015:2).
Pengawasan memiliki beberapa tipe. Menurut Fahmi (2014:185) ada tiga tipe pengawasan yaitu: 1). Pengawasan pendahuluan, atau sering disebut steering controls dirancang untuk mengantisipasi masalah-masalah atau penyimpanganpenyimpangan dari standar atau tujuan dan memungkinkan koreksi dibuat sebelum suatu tahap kegiatan tertentu diselesaikan; 2). Pengawasan concurrent, merupakan tipe pengawasan proses dimana aspek tertentu dari suatu prosedur harus disetujui dulu, atau syarat tertentu harus dipenuhi dulu sebelum kegiatankegiatan bisa dilanjutkan atau menjadi semacam peralatan double check yang lebih menjamin ketetapan pelaksanaan suatu kegiatan; 3). Pengawasan umpan balik, juga dikenal sebagai past-action controls adalah mengukur hasil-hasil dari suatu kegiatan yang telah diselesaikan.

Manullang (2010: 176-179) menyatakan, berdasarkan obyeknya, pengawasan dapat dibedakan atas pengawasan di bidang-bidang sebagai berikut: a). Produksi - pengawasan ditunjukan terhadap kuantitas hasil produksi ataupun terhadap kualitas ataupun terhadap likuiditas perusahaan; b). Waktu - pengawasan dibidang waktu bermaksud untuk menentukan, apakah dalam menghasilkan sesuatu hasil produksi sesuai dengan waktu yang telah direncanakan atau tidak; c). Keuangan pengawasan dibidang keuangan, dimaksudkan untuk mengetahui penggunaan keuangan apakah berjalan sesuai rencana atau tidak; d). Manusia dengan kegiatannya - pengawasan dibidang manusia dengan kegiatan-kegiatan yang bertujuan untuk mengetahui apakah kegiatan-kegiatan telah dijalankan sesuai dengan intruksi, rencana tata kerja manual atau belum.

Hubungan antara supervisi dan Kemampuan adaptasi dikemukakan oleh beberapa ahli. Supervisi yang baik akan meningkatkan kemampuan karyawan dalam beradaptasi dengan perubahan dan lingkungan baru (Necoranec dan Nagyova : 2014). Hubungan yang baik antara supervisor dan karyawan akan mempercepat adaptasi karyawan (Winata : 2016). Supervisi yang baik akan meningkatkan motivasi individu sehingga mereka lebih cepat beradaptasi (Koesindratmono : 2013).

\section{Kemampuan Kognitif dan Kemampuan Adaptasi}

Kemampuan kognitif adalah kapasitas individu saat ini untuk melakukan berbagai tugas dalam sebuah pekerjaan (Robbins, 2016:35). Kemampuan dasar adalah keterampilan yang dibutuhkan untuk 
melaksanakan pekerjaan dengan baik (Kaswan, 2017: 26). Kognitif adalah istilah umum yang mencakup segenap mode pemahaman, yakni persepsi, imajinasi, penangkapan makna, penilaian dan penalaran (Kuper dalam Desmita, 2014:97). Kognisi adalah apa yang diketahui individu mengenai diri mereka sendiri dan lingkungan mereka. Kognitif mengimplikasikan proses sadar dalam memperoleh pengetahuan (Ivancevich et al, 2007: 88).

Menurut Kaswan (2017:26-27) Kemampuan kognitif mengacu pada tiga dimensi yaitu: 1). Pemahaman Verbal. Kemampuan verbal merupakan kemampuan atau kapasitas seseorang memahami dan menggunakan bahasa lisan atau tulisan. Hal ini berhubungan dengan komunikasi organisasi seperti yang dipaparkan oleh Robbins (2016: 228) Sarana utama dalam menyampaikan pesan adalah komunikasi lisan. Keuntungan dari komunikasi lisan adalah kecepatan dan umpan balik. Kita dapat menyampaikan sebuah pesan verbal dan menerima tanggapan dalam waktu yang sedikit. Jika penerima belum yakin dengan pesannya, maka umpan balik yang cepat memungkinkan pengirim untuk mendeteksi secara cepat dan memperbaikinya. Sedangkan komunikasi secara tulisan meliputi surat, e-mail, pesan singkat, organisasional secara berkala, dan ataupun metode lain yang menyampaikan tulisan dengan kata-kata atau simbol. 20. Kemampuan Kuantitatif. Kemampuan kuantitatif menunjukkan seberapa cepat dan akurat seseorang dapat memecahkan masalah matematika. Kemampuan kuantitatif dapat disebut sebagai metode scientific karena memenuhi kaidahkaidah ilmiah yaitu konkrit, obyektif, terukur, rasional, dan sistematis. 3). Kemampuan Menalar / Berpikir. Kemampuan menalar atau berpikir adalah kapasitas seseorang menemukan solusi masalah. Kemampuan kognitif terkait dengan kinerja yang sukses dalam semua pekerjaan. Pentingnya kemampuan kognitif untuk kesuksesan pekerjaan bertambah ketika pekerjaan semakin kompleks.

Menurut Kaswan (2017: 27) Kemampuan kognitif mempengaruhi kinerja tugas/pekerjaan dan kemampuan belajar dalam pelatihan atau penyesuaian. Jika peserta pelatihan kurang memiliki tingkat kemampuan kognitif yang diperlukan untuk melaksanakan pekerjaan atau tugas, mereka tidak menghasilkan kinerja yang baik. Juga, tingkat kemampuan kognitif peserta latihan dapat mempengaruhi kinerja jika mereka dapat belajar dalam program pelatihan. Peserta pelatihan dengan tingkat kemampuan kognitif yang rendah cenderung tidak berhasil menyelesaikan atau memperoleh hasil yang rendah juga. Hasil penelitian Lora (2013) menemukan bahwa pelatihan dengan perlakuan pendekatan kognitif dapat mengurangi stress dalam penyesuaian diri.

\section{Komitmen Organisasi dan Kemampuan Adaptasi}

Komitmen organisasi adalah sikap kerja dalam wujud keinginan, kemauan, dedikasi, loyalitas atau kepercayaan yang kuat yang menunjukkan keinginan tetap menjadi bagian anggota organisasi dengan mau menerima nilai dan tujuan organisasi, bekerja untuk kepentingan organisasi (Kaswan, 2017: 225). Sedangkan menurut Daft (2010: 287) komitmen pada organisasi adalah kesetiaan dan keterkaitan pegawai pada organisasi. Menurut Robbins dan Judge (2016: 47) komitmen organisasi seorang pekerja mengidentifikasi sebuah organisasi, tujuan serta harapannya untuk tetap menjadi anggota.

Komitmen organisasi terdiri atas tiga dimensi sebagai berikut: 1). Komitmen afektif, merupakan komitmen yang dapat timbul pada diri sesorang karyawan dikarenakan adanya karakteristik individu, karasteristik struktur organisasi, signifikasi tugas, berbagai keahlian, umpan balik dari pemimpin, dan keterlibatan dalam manajemen. Karyawan yang memiliki komitmen afektif, cenderung untuk tetap dalam satu organisasi karena mereka percaya sepenuhnya misi yang dijalankan oleh organisasi. 2). Komitmen kelanjutan, merupakan komitmen yang didasari atas kekhawatiran seseorang terhadap kehilangan sesuatu yang telah diperoleh dari organisasi. 3). Komitmen normatif, menunjukkan tanggung jawab moral karyawan untuk tetap tinggal dalam organisasi. Penyebab timbulnya komitmen ini adalah tuntutan sosial yang merupakan hasil pengalaman dalam berinteraksi dengan sesama karena balas jasa, respek sosial, budaya atau agama.

Salah satu dimensi komitmen organisasi yaitu komitmen afektif yang timbul pada diri seorang karyawan dikarenakan adanya karaktersitik individu, karaktersitik organisasi, signifikansi tugas, berbagai keahlian, umpan balik pemimpin, dan keterlibatan dalam manajemen sehingga mengahasilkan kuatnya keinginan emosional karyawan untuk beradaptasi dengan nilai-nilai yang ada agar tujuan dan keinginannya untuk tetap diorganisasi dapat terwujud (Kaswan, 2017:227).

\section{Hipotesis}


Berdasarkan uraian diatas, kami mengajukan tiga buah hipotesis untuk diuji secara empiris sebagai berikut :

Hipotesis 1 : Semakin baik supervisi yang dilakukan, maka kemampuan karyawan untuk beradaptasi akan semakin cepat.

Hipotesis 2 : Karyawan yang mempuntyai kemampuan kognitif yang lebih baik, akan mampu beradaptasi lebih cepat.

Hipotesis 3 : Karyawan yang mempunyai komitmen organisasi lebih kuat, akan dapat beradaptasi lebih cepat.

\section{METODE PENELITIAN}

Penelitian ini merupakan penelitian dengan pendekatan kuantitatif. Unit analisisnya adalah karyawan sebuah perusahaan yang tetap dipertahankan ketika terjadi pergantian kepemilikan. Teknik sampling yang digunakan adalah sampling jenuh. Responden penelitian sebanyak 76 karyawan. Data dikumpulkan dengan kuesioner yang disusun dengan skala peringkat (rating scale). Untuk menganalisis hubungan antar variable digunakan multiple regreesion. Uji signifikansi pengaruh simultan dilakukan dengan uji f. sedangkan uji signifikansi pengaruh parsial digunakan uji t.

\section{HASIL DAN PEMBAHASAN}

Pada bagian ini akan dijelaskan hasil pengujian statistic mengenai pengaruh Supervisi, Kemampuan Kognitif, dan Komitmen Organisasi terhadap Kemampuan Adaptasi Karyawan, baik secara simultan maupun parsial. Dalam penelitian ini Supervisi diberi symbol dengan $X_{1}$, Kemampuan Kognitif diberi symbol $X_{2}$, dan Komitmen Organisasi diberi symbol $X_{3}$. Sementara itu Kemampuan Adaptasi sebagai variable dependen diberi symbol $Y$.

Hasil pengujian pengolahan data dengan multiple regression dengan SPSS menunjukan bahwa nilai koefisien determinasi $\left(R^{2}\right)$ adalah sebesar 0.392. Hal ini mengandung makna bahwa kemampuan prediksi variable Supervisi, Kemampuan Kognitif, dan Komitmen Organisasi terhadap Kemampuan Adaptasi Karyawan, adalah sebesar 39.2\%. Dengan kata lain, Kemampuan Adaptasi seorang karyawan ditentukan sebesar 39.2\% oleh Supervisi, Kemampuan Kognitif, dan Komitmen Organisasi. Selengkapnya data dapat dilihat pada table 1 .

Tabel 1. Model Summary

Model Summary ${ }^{\text {b }}$

\begin{tabular}{|l|c|c|c|c|c|}
\hline $\begin{array}{l}\text { Mode } \\
1\end{array}$ & $\mathrm{R}$ & $\mathrm{R}$ Square & $\begin{array}{c}\text { Adjusted R } \\
\text { Square }\end{array}$ & $\begin{array}{c}\text { Std. Error of } \\
\text { the Estimate }\end{array}$ & $\begin{array}{c}\text { Durbin- } \\
\text { Watson }\end{array}$ \\
\hline 1 & $.626^{\mathrm{a}}$ & .392 & .367 & 1.70010 & 1.978 \\
\hline
\end{tabular}

a. Predictors: (Constant), $\times 3, \times 2, \times 1$

b. Dependent Variable: $Y$

Sumber: data hasil olahan SPSS versi 16.0 (2017)

Dilihat dari nilai koefisien determinasi diatas, nampaknya tingkat prediksi variable Supervisi, Kemampuan Kognitif, dan Komitmen Organisasi terhadap Kemampuan Adaptasi nampaknya tidak terlalu besar, karena nilainya masih berada dibawah 50\%. Hal ini menunjukan bahwa masih ada factor-faktor atau predictor lain yang belum terungkap. Oleh karena itu, hal ini menjadi tantangan yang sangat menarik bagi penelitian selanjutnya, untuk bisa mengelaborasi factor-faktor lainnya sehingga menjadi lebih lengkap.

Tabel 2. ANOVA

ANOVA ${ }^{\text {b }}$

\begin{tabular}{|ll|r|r|r|r|r|}
\hline Madel & & Sum of & df & Mean Square & \multicolumn{1}{c|}{ F } & Sig. \\
\hline 1 & Regression & 134.181 & 3 & 44.727 & 15.475 & $.000=$ \\
& Residual & 208.105 & 72 & 2.890 & & \\
& Total & 342.286 & 75 & & & \\
\hline
\end{tabular}

a. Predictors: (Constant), $\times 3, \times 2, \times 1$

b. Dependent Variable: $Y$

Sumber: data hasil olahan SPSS versi 16.0 (2017) 
Meskipun nilai koefisien determinasinya relative kecil, namun hasil pengujian signifikansi dengan uji $f$ memperlihatkan nilai yang sgnifikan. Pada table 2 dapat dilihat bahwa nilai $F_{\text {hitung }}$ adalah sebesar 15.475 . Nilai $F_{\text {tabel }}$ pada taraf nyata $(\alpha) 5 \%$ dengan df1 : $4-1=3$ dan df2: $76-4=72$ adalah sebesar 2,726 (Hasil interpolasi).dengan demikian, dapat disimpulkan bahwa Supervisi, Kemampuan Kognitif, dan Komitmen Organisasi merupakan predictor yang signifikan terhadap Kemampuan Adaptasi Karyawan.

Selanjutnya akan dijelaskan pengaruh masing-masing variable predictor secara parsial. Derajat prediksi dapat dilihat berdasarkan nilai koefisien regresi. Dari table 3, dapat dilihat bahwa masing-masing variable memiliki koefisien regresi yang berbeda. Supervisi yang disimbolkan dengan $X_{1}$, memupnyai nilai koefisien regresi sebesar 0.301 atau $30.1 \%$. Sementara itu Kemampuan Kognitif $\left(X_{2}\right)$ mempunyai koefisien regresi sebesar 0.394 atau $39.4 \%$ dan Komitmen orhanisasi $\left(X_{3}\right)$ mempunyai nilai koefisien regresi sebesar 0.275 atau $27.5 \%$.

Tabel 3. Coefficients

Coefficients

\begin{tabular}{|c|c|c|c|c|c|c|c|c|}
\hline \multirow[b]{2}{*}{ Mad } & & \multicolumn{2}{|c|}{ Unstandardized Coefficients } & \multirow{2}{*}{$\begin{array}{c}\text { Standardized } \\
\text { Coefficients }\end{array}$} & \multirow[b]{2}{*}{$t$} & \multirow[b]{2}{*}{ Siq. } & \multicolumn{2}{|c|}{ Collinearity Statistics } \\
\hline & & B & Std. Error & & & & Tolerance & VIF \\
\hline \multirow[t]{4}{*}{1} & (Constant) & .092 & 1.865 & & .049 & .961 & & \\
\hline & $x_{1}$ & .301 & .160 & .183 & 1.882 & .064 & .893 & 1.120 \\
\hline & $\times 2$ & .394 & .079 & .471 & 4.993 & .000 & .949 & 1.054 \\
\hline & $\times 3$ & 275 & 114 & .230 & 2.407 & 019 & 927 & 1.078 \\
\hline
\end{tabular}

a. Dependent Variable: $Y$

Sumber: data hasil olahan SPSS versi 16.0 (2017)

Dari hasil pengolahan data tersebut, secara matermatis, kita dapat menuliskan persamaan regresi sebagai berikut:

$$
Y=0.092+0.301 X_{1}+0.394 X_{2}+0.275 X_{3}+\varepsilon
$$

Persamaan regresi diatas menunjukkan bahwa koefisien regresi $(\beta)$ untuk variabel Supervisi $\left(X_{1}\right)$, Kemampuan Kognitif $\left(X_{2}\right)$ dan Komitmen Organisasi $\left(X_{3}\right)$ adalah bernilai positif. Artinya, ketiga variabel tersebut berpengaruh positif terhadap Kapabilitas Adaptasi ( $Y$ ).

Variabel Supervisi $\left(X_{1}\right)$ memiliki nilai koefisien regresi $\left(\beta_{1}\right)$ sebesar 0,301 . Hal ini menunjukkan bahwa setiap perbaikan Supervisi $\left(X_{1}\right)$ satu satuan nilai akan menaikkan Kapabilitas Adaptasi 0,301 satuan nilai. Variabel Kemampuan Kognitif $\left(\mathrm{X}_{2}\right)$ memiliki nilai koefisien regresi $\left(\beta_{2}\right)$ sebesar 0,394 . Hal ini menunjukkan bahwa setiap peningkatan variabel Kemampuan Kognitif $\left(X_{2}\right)$ satu satuan nilai akan menaikkan Kapabilitas Adaptasi 0,394 satuan nilai. Variabel Komitmen Organisasi $\left(X_{3}\right)$ memiliki nilai koefisien regresi $\left(\beta_{3}\right)$ sebesar 0,275 . Hal ini menunjukkan bahwa setiap peningkatan variabel Komitmen Organisasi $\left(X_{3}\right)$ satu satuan nilai akan menaikkan Kapabilitas Adaptasi 0,275 satuan nilai.

Berdasarkan table 3 diatas, dapat dilihat nilai signifikansi masing-masing variable.
Supervisi $\left(X_{1}\right)$ mempunyai nilai $t_{\text {hitung }}$ sebesar 1.882 dengan nilai sig 0.064 . Nilai tersebut lebih besar dibandingkan alpha (5\%). Dengan demikian dapat dikatakan bahwa Supervisi tidak berpengaruh signifikan terhadap Kemampuan Adaptasi Karyawan. Selanjutnya, Kemampuan Kognitif $\left(X_{2}\right)$ mempunyai nilai $t_{\text {hitung }}$ sebesar 4.993 dengan nilai sig 0.000 . Nilai tersebut lebih kecil dibandingkan alpha (5\%). Dengan demikian dapat dikatakan bahwa Kemampuan Kognitif berpengaruh signifikan terhadap Kemampuan Adaptasi Karyawan. Sementara itu, Komitmen Organisasi $\left(\mathrm{X}_{3}\right)$ mempunyai nilai $t_{\text {hitung }}$ sebesar 2.407 dengan nilai sig 0.019 . Nilai tersebut lebih kecil dibandingkan alpha $(5 \%)$. Dengan demikian dapat dikatakan bahwa Komitmen Organisasi berpengaruh signifikan terhadap Kemampuan Adaptasi Karyawan.

Mengapa Supervisi tidak berpengaruh signifikan? Banyak kemungkinan yang menyebabkan demikian. Salah satunya adalah kualitas kegiatan supervisi. Dibanyak perusahaan, kegiatan supervisi seringkali hanya bersifat "ritual" saja. Kegiatan supervisi lebih banyak dilihat dari aspek administrasi. Misalnya, memimpin kegiatan briefing sebelum melakukan aktivitas kerja kepada seluruh karyawan yang dilakukan oleh seorang supervisor, tidak dijadikan sebagai ajang untuk mengevaluasi dan mendiskusikan pekerjaan atau mencari solusi sebuah masalah. Kegiatan tersebut cenderung menjadi rutinitas belaka. Jika briefing sudah dilakukan, maka kewajiban 
supervisor sudah terpenuhi, tanpa melihat aspek kualitas dan content yang dibahas dalam briefing tersebut.

\section{E. PENUTUP \\ Kesimpulan}

Berdasarkan hasil analisis secara empiris, dapat diketahui bahwa Supervisi, Kemampuan Kognitif, dan Komitmen Organisasi merupakan determinan yang signifikan bagi Kemampuan Adaptasi. Selanjutnya, hasil analisis menunjukan bahwa secara parsial, Supervisi tidak berpengaruh signifikan terhadap kemampuan adaptasi. Sementara itu, Kemampuan Kognitif dan Komitmen Organisasi berpengaruh positif dan signifikan terhadap kemampuan adaptasi karyawan.

\section{Saran}

Terkait dengan hasil tersebut, penulis merekomendasikan agar kegiatan supervisi lebih memperhatikan kualitas ketimbang rutinitas. Kegiatan supervise hendaknya tidak sekedar memenuhi aspek administrasi saja. Sementara itu, kemampuan kognitif dan komitmen organisasi hendaknya mendapat perhatian penting bagi perusahaan. Artinya, dalam proses rekrutmen karyawan baru, salah satu kriteria penting yang harus diperhatikan adalah talenta karyawan yang mempunyai kapasitas kognitif yang memadai serta memiliki komitmen yang tinggi.

\section{F. DAFTAR PUSTAKA}

1. Alma, Buchari. 2013. Pengantar Bisnis. Bandung: Alfabeta.

2. Aziz, Aulia Habibul. 2015. Peranan Kemampuan Bersosialisasi dan Beradaptasi Terhadap Motivasi Belajar Siswa Kelas XI Jurusan Teknik Gambar Bangunan SMKN 3 Yogyakarta. Skripsi. Sarjana Universitas Negeri Yogyakarta.

3. Daft, Richard L. 2010. New Era of Management. Menjadi Era Baru Manajemen. Jakarta: Salemba Empat.

4. Desmita. 2014. Psikologi Perkembangan Peserta Didik. Bandung: Remaja Rosdakarya.

5. Fahmi, Irham. 2014. Manajemen Produksi dan Operasi. Bandung: Alfabeta.

6. Fahmi, Irham. 2015. Manajemen Kinerja. Bandung: Alfabeta.

7. Ghozali, Imam. 2013. Aplikasi Analisis Multivariate dengan Program SPSS. Edisi $\mathrm{Ke}$ tujuh. Semarang: Badan Penerbit Universitas Diponegoro.

8. Handono, Oki Tri dan Bashori Khoiruddin. 2013. Hubungan Antara Penyesuaian Diri dan Dukungan Sosial Terhadap Stres
Lingkungan pada Santri Baru. Jurnal Fakultas Psikologi. Vol.1, No 2. Hal 1-12.

9. Hastuti, Heni. 2008. Kemampuan Penyesuaian Diri. Jurnal Keperawatan Muhammadiyah. Hal 1-6.

10.Ivancevich, John M.et al. 2007. Perilaku dan Manajemen Organisasi. Jakarta: Erlangga.

11. Katamuthu, Kanagaletchumy. 2012. Impact of Leadership Styles on Employee Adaptability in Call Center. Quantitative Study. Universitas Sains Malaysia.

12.Kaswan. 2017. Psikologi Industri dan Organisasi. Bandung: Alfabeta.

13.Kurniawan, Agung Hudi. 2012. Pengaruh Kemampuan Kognitif Terhadap Kemampuan Psikomotorik Mata Pelajaran Produktif Alat Ukur Siswa Kelas $X$ Jurusan Teknik Kendaraan Ringan Di SMK Muhammadiyah Prambanan. Skripsi. Sarjana Universitas Negeri Yogyakarta.

14.Lora, Meysie Diyanna. 2013. Pengaruh Pendekatan Kognitif Untuk Mengurangi Stres dalam Penyesuaian Diri pada Mahasiswa Ahmad Dahlan Angkatan 2013/2014. Jurnal Fakultas Psikologi. Hal 117

15.Manullang, M. 2010. Dasar-dasar Manajemen. Yogyakarta: Gadjah Mada University Press.

16. Nekoranec, Jaroslave dan Nagyova. 2014. Adaptation of Employees in The Organization and Its Importance in Terms of Human Resource Management. Journal of Management and Economics. Page 1-6.

17.Purwanto, Ngalim. 2009. Administrasi dan Supervisi Pendidikan. Bandung: Remaja Rosdakarya.

18. Ratcovic, Biljana dan Kostic. 2014. Impact of Organizational Socialization Towards Employees Social Adaptation. Journal of Engineering Management And Competitiveness (JEMC). Vol 4, No. 1. Page 1-7.

19.Robbins, Stephen P dan Coutler. 2010. Manajemen. Jakarta: Erlangga.

20.Robbins. Stephen $P$ dan Timothy A. Judge.2016. Organization Behaviour: menjadi Perilaku Organisasi. Jakarta: Salemba Empat.

21.Semiun, Yustinus. 2007. Kesehatan Mental 1. Yogyakarta: Kanisius.

22.Siagian, Sondang P. 2010. Teori dan Praktek Kepemimpinan. Jakarta : Rineka Cipta.

23.Siagian, Sondang P. 2015. Manajemen Sumber Daya Manusia. Jakarta: Bumi Aksara.

24.Sugiyono. 2016. Metode Penelitian. Bandung: Alfabetha. 


\section{Catatan :}

Artikel ini telah dipresentasikan dalam Festival Riset IImiah Manajemen dan Akuntansi Tahun 2018 (FRIMA 2018) yang diselenggarakan Oleh STIE STEMBI - Bandung Business School, dan abstraknya dimuat dalam Prosiding FRIMA 2018 dengan ISSN No 2614-6681. Selanjutnya, kami melakukan beberapa revisi terhadap artikel ini untuk menyempurnakan isi dan kedalaman pembahasan, agar dapat diterbitkan dalam jurnal INTEKNA. 